Isna Rahmawati,, Metode Bermain untuk Meningkatkan Nilai Sosial Siswa dalam Pembelajaran IPS...

\title{
Metode Bermain untuk Meningkatkan Nilai Sosial Siswa \\ dalam Pembelajaran IPS di SDN 3 Karanganom Klaten Utara
}

\author{
Isna Rahmawati \\ PGSD Universitas Widya Dharma Klaten \\ isnarahma@unwidha.id
}

\begin{abstract}
Abstrak
Nilai sosial akhir-akhir ini menjadi persoalan yang muncul dalam dunia pendidikan. Sikap individualisme, lunturnya kebersamaan dan saling menghargai sudah menjangkiti siswa sekolah dasar. Penelitian ini bertujuan untuk meningkatkan nilai sosial dengan menggunakan metode bermain dalam pembelajaran IPS di kelas IV SDN 3 Karanganom Klaten Utara. Penelitian ini adalah penelitian tindakan kelas dengan model siklus dari Kemmis \& Taggart. Penelitian ini dilaksanakan sebanyak enam pertemuan dalam dua siklus. Teknik pengumpulan data dan instrumen penelitian meliputi observasi dengan lembar observasi, dokumentasi, dan catatan lapangan serta wawancara dengan pedoman wawancara.

Hasil penelitian menunjukkan bahwa nilai sosial siswa dapat ditingkatkan dengan menerapkan metode bermain. Melalui kegiatan bermain anak terlatih untuk saling bekerjasama baik dalam satu kelompok maupun antar kelompok dan terlatih untuk saling menghargai orang lain dalam memecahkan sandi dan menemukan makna yang terkandung di dalam kegiatan bermain. Melalui metode bermain nilai sosial siswa mengalami peningkatan secara kontinyu dari siklus ke siklus. Rata-rata skor nilai sosial siswa sebelum dilakukan tindakan adalah sebesar 37,26 meningkat menjadi 41,83 setelah dilakukan tindakan pada siklus 1 . Selanjutnya pada siklus 2 meningkat menjadi 52,64.
\end{abstract}

Kata Kunci: Nilai, Nilai Sosial, Metode Bermain, Siswa SD

\section{PENDAHULUAN}

Fungsi dan tujuan kurikulum IPS di sekolah dasar menjelaskan bahwa pendidikan IPS sangat penting bagi anak dalam kehidupannya, baik sebagai warga negara, warga masyarakat, maupun sebagai individu. Maka pembelajaran IPS hendaknya mampu mengembangkan berbagai dimensi, baik dimensi pengetahuan, sikap, maupun keterampilan. IPS berfungsi mengembangkan kompetensi pengetahuan, sikap, dan keterampilan dasar untuk memahami permasalahan sosial yang dihadapi siswa dalam kehidupan. (Isjoni, 2011).

Pada dasarnya mempelajari IPS adalah mengembangkan pengetahuan, nilai, sikap, serta keterampilan sosial siswa untuk dapat menelaah kehidupan sosial yang dihadapi dalam kehidupan sehari-hari yang bertujuan supaya siswa mampu mengembangkan pengetahuan, nilai, dan sikap, serta keterampilan sosial yang berguna bagi dirinya.

Pendidikan dasar dalam penyelenggaraan pendidikan adalah sebagai bagian dari sistem pendidikan nasional sebagai wahana untuk memberikan pengetahuan dan mengembangkan nilainilai sehingga keberadaannya sangat penting. Sejak di tingkat sekolah dasar secara dini guru seharusnya menyadari bahwa pendidikan bukan hanya sekedar untuk menyampaikan materi pelajaran, namun juga untuk mengembangkan nilainilai guna pembentukan kepribadian siswa. 
Ironisnya, sekolah sebagai institusi pembentuk insan cerdas yang berakhlak mulia banyak terjebak dalam formalitas pendidikan. Penyelenggaraan pendidikan lebih menekankan pada bagaimana siswa bisa menyelesaikan materi ajar secara tuntas dan lulus dengan nilai yang tinggi sehingga proses penanaman nilai menjadi terabaikan.

Ada kecenderungan dari beberapa guru yang mengajar hanya menekankan pengembangan kemampuan kognitif sementara kemampuan aspek afektif dan psikomotorik kurang diperhatikan. Untuk memenuhi target kurikulum, dalam pembelajarannya guru cenderung menekankan penguasaan materi dan tidak didukung dengan metode pembelajaran yang dapat dipergunakan untuk menggali pemahaman anak didik tentang nilai-nilai yang terkandung di dalam materi pembelajaran.

Kendala bagi guru untuk dapat mengoptimalkan penanaman nilai pada siswa sebagai bagian dari pengembangan kemampuan afektif bagi siswa adalah karena terlalu banyaknya materi bahasan yang dibebankan oleh kurikulum dengan keterbatasan waktu yang tersedia. Selain itu, metode pembelajaran dan pendekatan yang dipergunakan dalam proses pembelajaran merupakan masalah utama dalam pembelajaran dewasa ini. Kenyataan yang ada menunjukkan bahwa model pembelajaran yang digunakan guru belum ideal. Banyak guru yang hanya menggunakan srategi pembelajaran konvensional yaitu metode ceramah.

Fokus pendidikan saat ini masih banyak berkutat pada persoalan kognitif. Sementara segi afektif dan psikomotor kurang mendapat perhatian. Kurikulum sebagian besar porsinya hanya merancang bagaimana siswa menjadi anak yang cerdas secara intelektual, berprestasi, nilainya tinggi, dan mendapat ranking bagus. Sementara moralitas siswa, daya kreatifitas, serta tingkah laku, tidak begitu diperhatikan. Akibatnya siswa menjadi manusia egois, tidak patuh pada norma, dan cuek dalam segala perbuatannya (Fatkhul Anas, 2009).

Lebih lanjut Wina Sanjaya (2008) mengemukakan bahwa proses pendidikan sesuai dengan kurikulum yang berlaku selama ini cenderung diarahkan untuk pembentukan intelektual. Kemampuan intelektual (kognitif) menjadi penentu keberhasilan proses pendidikan di sekolah. Hal tersebut berakibat terhadap upaya yang dilakukan oleh setiap guru diarahkan agar siswa dapat menguasai pengetahuan sesuai dengan standar isi kurikulum yang berlaku.

Persoalan yang muncul dalam dunia pendidikan akhir-akhir ini sangat terkait dengan aspek-aspek sosial. Peristiwaperistiwa konflik yang terjadi di berbagai daerah merupakan bukti bahwa pemahaman nilai-nilai sosial masih sangat lemah. Konflik-konflik yang terjadi merupakan suatu cerminan dari ketidakmampuan dalam membangun hubungan yang harmonis dengan sesama.

Dalam dunia pendidikan, khususnya siswa sekolah dasar, hal itu dapat dilihat dari kondisi di lapangan yang menunjukkan munculnya sikap individualisme pada siswa. Budaya kekerasan, lunturnya kebersamaan dan saling menghargai di antara sesama sudah mulai menjangkiti pada siswa sekolah dasar.

Indikasi rendahnya nilai sosial pada anak dapat terlihat dari fenomena yang ada di sekolah. Saling ejek di antara siswa yang berujung dengan perkelahian di sekolah sudah sangat sering terlihat dan terdengar. Budaya gotong royong, bekerjasama secara positif, dan tolong menolong di antara siswa juga terlihat mulai luntur. Perilaku anak cenderung bersikap cuek, masa bodoh 
terhadap orang lain, dan hanya mementingkan atau mengutamakan diri sendiri.

Berdasarkan hasil observasi dan wawancara di kelas IV SDN 3 Karanganom Klaten Utara ditemukan indikasi rendahnya nilai sosial siswa pada aspek kerjasama dan saling menghargai. Hal tersebut terlihat selama proses pembelajaran IPS beberapa siswa nampak tidak fokus terhadap guru yang sedang menyampaikan materi pelajaran. Beberapa siswa terlihat ribut, ngobrol, gojeg, berkata dengan kasar terhadap temannya. Pada waktu kegiatan kelompok siswa masih memilih-milih teman. Terlihat juga beberapa siswa saling menyalahkan dengan hasil perolehan kerja kelompoknya.

Selain itu, terdapat beberapa siswa saling mengolok/mengejek manakala terdapat siswa yang mengerjakan tugas kurang tepat. Ketika ada siswa yang tidak tepat atau keliru dalam menjawab pertanyaan dari guru, siswa yang lain mengejek, menyoraki dan mentertawakannya. Siswa yang tidak ditunjuk oleh guru nyletuk menjawab, dan ada yang mengejek karena siswa yang ditunjuk oleh guru tidak segera menjawab pertanyaan guru.

Perilaku yang diperlihatkan siswa tersebut di atas menunjukkan bahwa masih banyak terdapat siswa yang belum melaksanakan nilai-nilai sosial dengan baik. Siswa belum melakukan kerjasama dan saling menghargai dengan baik sehingga perlu segera dilakukan suatu tindakan untuk memperbaiki perilaku tersebut yaitu dengan menerapkan metode bermain dalam pembelajaran IPS.

Pada fase anak usia sekolah dasar, anak cenderung untuk bermain, oleh karena itu tidak ada salahnya jika metode bermain dapat diterapkan dalam proses pendidikan pada masa tersebut. Bermain mempunyai peranan penting dalam pembinaan pribadi anak. Aktivitas bermain membantu anak mencapai perkembangan yang utuh, baik perkembangan fisik, intelektual, sosial, moral, maupun emosional.

Pendidikan usia sekolah dasar memegang peranan penting sebagai pondasi bagi dasar kepribadian anak yang akan menentukan sejarah perkembangan anak selanjutnya. Oleh karena itu, diperlukan pendidikan dan pelayanan yang tepat, pemberian pengalaman awal yang posistif serta stimulasi yang sesuai dengan tingkat perkembangannya.

\section{METODE}

Penelitian ini merupakan Penelitian Tindakan Kelas model Kemmis \& Taggart (1988) yang mana pada tiap siklusnya terdiri atas perencanaan, tindakan, observasi, dan refleksi. Tujuan dari model tersebut adalah jika ditemukan adanya kekurangan pada awal pelaksanaan tidakan, maka dapat dilakukan perbaikan pada tindakan atau siklus berikutnya sampai target yang diinginkan tercapai. Adapun kriteria keberhasilan dalam penelitian ini yaitu jika terjadi peningkatan nilai sosial siswa pada aspek kerjasama dan saling menghargai.

Penelitian ini dilaksanakan di kelas IV SDN 3 Karanganom Klaten Utara. Pemilihan lokasi penelitian adalah berdasarkan pada hasil observasi awal yang dilakukan peneliti terhadap sekolah. Dari hasil observasi awal tersebut peneliti bersama pihak sekolah menyepakati untuk menindaklanjuti sebagai upaya melakukan perbaikan.

Kegiatan penelitian ini dilaksanakan pada bulan Mei sampai dengan bulan Juli 2018. Pelaksanaan tindakan disesuaikan dengan jadwal kegiatan pembelajaran di sekolah. 
Teknik dan pengumpulan data dan instrumen dalam peneliti ini yaitu observasi, wawancara dan dokumentasi. Observasi dilakukan dengan menggunakan lembar observasi selama proses pembelajaran IPS. Hal-hal yang diamati dalam observasi adalah perilaku nilai sosial siswa pada aspek kerjasama dan saling menghargai.

Wawancara dilakukan guna mendapatkan informasi yang mendukung hasil observasi. Serta dokumentasi rekaman aktifitas yang terjadi pada pembelajaran pada waktu dilakukan tindakan guna mengungkap data-data yang bersifat dokumenter sehingga mendapatkan gambaran keadaan siswa pada waktu dilakukan tindakan.

Analisis penelitian ini menggunakan analisis yang bersifat deskriptif kualitatif sebagaimana yang dikemukakan oleh Mills (Nana Syaodih Sukmadinata, 2007). Analisis data dilakukan sesuai karakteristik masing-masing data yang terkumpul. Data yang terkumpul diklasifikasikan dan dikategorikan secara sistematis menurut karakteristiknya. Hasil penelitian disajikan dalam bentuk narasi, tabel, dan grafik.

Analisis data dalam penelitian ini dengan merefleksikan hasil pengamatan selama pelaksanaan tindakan yang dilakukan pada tiap siklus. Proses refleksi dijalankan secara kolaboratif antara peneliti, pengamat, dan guru untuk melihat, mengkaji, menilai dan mempertimbangkan hasil tindakan selama proses perbaikan, serta pencapaian hasil dari tindakan yang dilakukan.

\section{HASIL PENELITIAN DAN PEMBAHASAN}

Nilai sosial siswa pada aspek kerjasama dan saling menghargai di kelas IV SDN Karanganom 3 Klaten Utara sebelum dilakukan tindakan masih banyak yang negatif. Hal tersebut terlihat dari perilaku yang ditunjukkan siswa selama proses pembelajaran IPS sebelum dilakukan tindakan. Pada waktu guru menjelaskan materi pelajaran siswa Nampak tidak memperhatikan. Siswa banyak yang nylethuk, gojeg, dan berbicara sendiri dengan temannya. Selain itu siswa juga tidak memperhatikan temannya yang sedang menyampaikan pendapatnya. Siswa saling mengolok/mengejek dan berkata kasar. Pada waktu kegiatan kelompok siswa masih memilih-milih teman. Terlihat juga beberapa siswa saling menyalahkan dengan hasil perolehan kerja kelompoknya.

Selain itu, terdapat beberapa siswa saling mengolok/mengejek manakala terdapat siswa yang mengerjakan tugas kurang tepat. Ketika dalam menjawab pertanyaan guru ada siswa yang tidak dapat atau keliru/kurang tepat, siswa yang lain mengejek, menyoraki dan mentertawakannya. Siswa yang tidak ditunjuk oleh guru nyletuk menjawab, dan ada yang mengejek karena siswa yang ditunjuk oleh guru tidak segera menjawab pertanyaan guru.

Berdasarkan hasil observasi dan wawancara dalam melakukan pembelajaran guru sudah berusaha menggunakan metode pembelajaran yang bervariatif, yaitu ceramah yang diselingi dengan tanya jawab, serta diskusi. Namun metode ceramah lebih banyak digunakan dalam pembelajaran karena dianggap dapat mengatasi materi yang banyak dengan alokasi waktu yang tersedia. Selain itu Guru juga sudah menggunakan media dalam pembelajaran.

Berdasarkan hal tersebut penelitian ini dilakukan untuk meningkatkan nilai-nilai sosial siswa pada aspek kerjasama dan saling menghargai dengan menggunakan metode ceramah yang diselingi kegiatan bermain. Metode bermain ini melatih siswa 
untuk bekerjasama dan saling menghargai dengan temannya dalam satu kelompok dan antar kelompok.

Kegiatan bermain yang diterapkan dalam penelitian ini dilakukan secara kelompok. Tiap kelompok terdiri dari 2-3 orang siswa, agar semua siswa berperan aktif dalam melakukan permainan. Kegiatan bermain ini akan dapat berjalan dengan baik jika siswa dalam melakukan permainan siswa saling bekerjasama dan saling saling menghargai satu dengan yang lain dalam satu kelompok maupun antar kelompok.

Selain metode bermain, materi juga menjadi hal yang sangat penting dalam pembelajaran. Materi yang dipilih digunakan yaitu materi yang sesuai serta dapat diintegrasikan dengan nilai soial (kerjasama dan saling menghargai) dan dalam kegiatan bermain.

Siswa dikatakan sudah meningkat nilai sosialnya jika siswa telah menunjukkan perilaku positif. Siswa sudah lebih baik dalam melakukan kerjasama dan lebih bisa menghargai orang lain.

Hasil penelitian ini menunjukkan bahwa nilai sosial siswa pada aspek kerjasama dan saling menghargai mengalami peningkatan secara kontinyu dari siklus ke siklus. Peningkatan perilaku kerjasama siswa dapat terlihat dari perilaku siswa pada saat melakukan kegiatan bermain secara bersama-sama. Selama kegiatan bermain, siswa berinteraksi dan berpartisipasi secara baik dengan anggota kelompok. Siswa tidak memaksakan kehendaknya pada kelompok. Siswa dapat menerima hasil keputusan kelompok dan melaksanakan tugas yang telah ditetapkan oleh kelompok, dan siswa menjunjung tinggi hasil kerja kelompok tersebut.

$$
\text { Peningkatan perilaku saling }
$$
menghargai siswa terlihat pada saat pembagian kelompok. Siswa mau menerima siapapun teman yang menjadi anggota kelompoknya. Selain itu pada waktu melakukan diskusi mengartikan sandi, siswa menghargai pendapat temannya, tidak memaksakan pendapat dan menghargai keberadaan temannya dalam kelompok, serta belajar untuk tidak mengolokolok/mengejek temannya kelompok lain yang salah dalam mengartikan sandi dan menjawab pertanyaan.

Hasil penelitian ini sesuai dengan tujuan permainan yang diterapkan dalam pembelajaran, yaitu permaian "Pecahkan Sandi Temukan Makna" yang merupakan gabungan dari permainan "Utak Atik Sandi", "Mencari Adik Kakak", dan "Pasaran". Permainan "Utak Atik Sandi" bertujuan untuk melatih anak bekerjasama. Siswa melakukan kerjasama dalam tim untuk menerjemahkan kata-kata rahasia (Vincentius Endy Sntosa \& Iin Mendah Mulyani, 2008). Permainan "Mencari Adik Kakak" bertujuan untuk membangun sikap saling menghormati (Muksin, 2009), dan permainan "Pasaran" bertujuan untuk melatih anak bekerjasama, berkomunikasi dan bersopan santun. Siswa saling berinteraksi dan berkomunikasi dengan sopan santun dalam melakukan permainan (Nora Regina, 2009).

Selanjutnya untuk melihat peningkatan nilai sosial siswa dapat dilihat dari rata-rata skor hasil observasi nilai sosial pra tindakan, siklus I, siklus II, siklus III pada tabel 1. Berdasarkan tabel 1 dapat diketahui bahwa rata-rata skor nilai sosial siswa sebelum dilakukan tindakan adalah 37,26 dengan rata-rata skor terendah sebesar 6,25 dan tertinggi 81,25. Pada sikus I meningkat menjadi 41,83 dengan rata-rata skor terendah sebesar 12,5 dan tertinggi 87,75. Pada siklus II meningkat menjadi 52,64 dengan rata-rata skor terendah sebesar 25 dan tertinggi 93,75. Hasil tersebut 
menunjukkan bahwa dari satu siklus ke siklus berikutnya nilai sosial siswa mengalami peningkatan

Tabel 1

\section{Skor Nilai Sosial Siswa}

\begin{tabular}{|c|c|c|}
\hline No & Siswa & $\begin{array}{r}\text { Sebelum } \\
\text { Tindakan }\end{array}$ \\
\hline 1 & 1 & \\
\hline 2 & 2 & \\
\hline 3 & 3 & \\
\hline
\end{tabular}
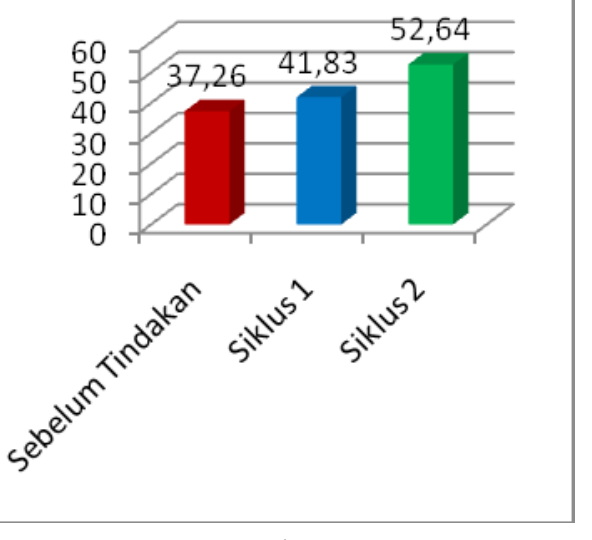

Gambar 1

Peningkatan Nilai Sosial Siswa

Tiap Siklus

Gambar 1 menunjukkan dengan jelas bahwa dengan diterapkannya metode bermain dalam pembelajaran IPS nilai sosial siswa mengalami peningkatan. Rata-rata persentase nilai sosial siswa mengalami peningkatan secara kontinyu pada setiap siklusnya.

Rata-rata skor nilai sosial siswa sebelum dilakukan tindakan adalah sebesar 37,26. Setelah dilakukan tindakan pada siklus I, rata-rata skor nilai sosial siswa meningkat menjadi 41,83. Rata-rata skor nilai sosial siswa pada siklus I mengalami peningkatan sebesar 4,57 dari sebelum dilakukan tindakan.

Selanjutnya pada siklus II, rata-rata skor nilai sosial siswa mengalami peningkatan yang lebih baik jika

Adapun peningkatan nilai sosial siswa secara lebih jelas dapat dilihat pada gambar 2 berikut ini. dibandingkan kenaikan pada siklus I. Hal ini terlihat dari rata-rata skor nilai sosial siswa pada siklus I sebesar 41,83 meningkat menjadi 52,64 pada siklus II. Nilai sosial siswa pada siklus II mengalami peningkatan skor sebesar 10.81 dari siklus I.

Hasil penelitian ini sesuai dengan hasil penelitian yang dilakukan oleh Siti Anafiah dan Ardian Arief (2017) bahwa dalam permainan bahasa terdapat nilai pendidikan karakter, diantaranya melatih anak untuk mampu bertanggung jawab dan 
kerjasama dengan teman yang lain. Selain itu hasil penelitian yang dilakukan oleh Sudrajat, Taat Wulandari, dan Agustina Tri Wijayanti. (2015) bahwa penanaman karakter dapat dilakukan melalui permainan tradisional sehingga nilai-nilai seperti kerjasama, kebersamaan, kreatifitas, tanggung jawab, demokrasi, percaya diri, komitmen dapat tertanam dalam diri anak berkembang dengan baik sejak usia dini.

Selain itu, hasil penelitian ini juga sesuai dengan teori yang disampaikan oleh Gulo (Wina Sanjaya, 2008) bahwa pengembangan aspek afektif pada nilai tidak bisa dipisahkan dari aspek kognitif dan psikomotorik. Masalah nilai merupakan masalah emosional. Oleh karena itu nilai dapat berkembang sehingga dapat dibina. Perkembangan nilai tidak terjadi sekaligus, tetap secara bertahap.

Permainan dapat membuat anak memperoleh keahlian berinteraksi dengan orang lain. Melalui permainan anak dapat belajar tentang kebiasaan-kebiasaan mengendalikan diri, kebiasaan bergaul, dan percaya pada diri sendiri. Melalui permainan perkembangan psikologis, intelektual, sosial, dan emosional pada anak dapat terwujud ('Athif Abul'id \& Syeikh Muhammad Sa'id Marsa, 2009).

Selain itu juga sesuai dengan Catron dan Allen (Tadkiroatun Musfiroh, 2008) bahwa bermain dapat mendukung perkembangan sosialisasi anak dalam hal interaksi sosial, yakni interaksi dengan teman sebaya dan orang dewasa; kerjasama, yaitu saling membantu, berbagi, dan bergiliran; peduli terhadap orang lain, seperti memahami dan menerima perbedaan individu.

Anak mempelajari banyak hal dalam bermain, antara lain belajar tingkah laku sosial, seperti bergiliran bicara, bekerja sama, berbagi, dan saling membantu. Anak belajar untuk mampu mengungkapkan ide dan perasaannya secara verbal, menyimak tuturan orang lain, dan memahami sudut pandang orang lain. Anak belajar menghargai dan mempedulikan orang lain dan saling menjaga satu sama lain, dan lain sebagainya (Tadkiroatun Musfiroh, 2008).

\section{SIMPULAN}

Berdasarkan hasil penelitian dapat disimpulkan bahwa Nilai sosial siswa dapat ditingkatkan dengan menerapkan metode bermain "Pecahkan Sandi Temukan Makna" dalam pembelajaran IPS. Melalui kegiatan bermain anak terlatih untuk saling bekerjasama baik dalam satu kelompok maupun antar kelompok dan terlatih untuk saling menghargai orang lain dalam memecahkan sandi dan menemukan makna yang terkandung di dalam sandi.

Melalui metode bermain nilai sosial siswa mengalami peningkatan secara kontinyu dari siklus satu siklus ke siklus berikutnya. Rata-rata skor nilai sosial siswa sebelum dilakukan tindakan adalah sebesar 37,26 meningkat menjadi 41,83 setelah dilakukan tindakan pada siklus 1. Selanjutnya pada siklus 2 meningkat menjadi 52,64.

\section{SARAN}

1. Guru hendaknya dapat memanfaatkan metode bermain dalam kegiatan pembelajaran agar siswa bisa menyerap dan mengamalkan nilai-nilai yang terkandung dalam materi pelajaran.

2. Perlu dilakukan penelitian lebih lanjut untuk lebih dapat meningkatkan nilai sosial siswa yang lebih baik lagi. 


\section{DAFTAR PUSTAKA}

'Athif Abul'id \& Syeikh Muhammad Sa'id Marsa. (2009). Bermain lebih baik daripada nonton tv. Surakarta: Ziyad Visi Media.

Andang Ismail. (2006). Education games, menjadi cerdas dan ceria dengan permainan edukatif. Yogyakarta: Pilar Media.

Arifudin. (2017). Penerapan Metode Simulasi Untuk Meningkatkan Kemampuan Berbicara Pada Siswa Kelas V Sekolah Dasar Negeri No 1 Banjar Tegal Singaraja. Diambil pada tanggal 30 Desember 2017 dari https://lambitu.wordpress.com/2009/ 12/29/penerapan-metode-permainansimulasi-untuk-meningkatkankemampuan-berbicara-pada-siswakelas-v-sekolah-dasar-negeri-no-1banjar-tegal-singaraja/.

Encyclopedia of Children's Health. (2010). Play. Diambil pada tanggal 10 Januari 2010, dari http://www.healthofchildren.com/P/ Play.html.

Fatkhul Anas, (2009). Relevansi pendidikan nilai untuk anak. Diambil pada tanggal 10 Juni 2009, dari http://groups.yahoo.com/group/mess age/6675.

Isjoni. (2007). Integrated learning, pendekatan pembelajaran IPS di pendidikan dasar. Pekanbaru: Falah Production.

Kemmis, S. And Mc. Taggart, R. (1991). The action research planner. Victoria: Deakin University.
Muksin. (2009). Outbound for kids kumpulan permainan kreatif dan komunikatif. Yogyakarta: Cosmic Books.

Nana Syaodih Sukmadinata. (2007). Metode penelitian pendidikan. Bandung: Remaja Rosdakarya.

Nora Regina. (2009). 120 permainan kreatif untuk menggali kecerdasan anak. Yogyakarta: Wahana Totalita Publisher.

Siti Anafiah dan Ardian Arief. (2017). Penanaman Pendidikan Karakter Melalui Permainan Bahasa pada Siswa SD Kota Yogyakarta. Diambil pada tanggal 30 Desember 2017 dari http://journal.ustjogja.ac.id/downloa d/ARTIKEL_SEMNAS UST.pdf

Sudrajat, Taat Wulandari, Agustina Tri Wijayanti. (2015). Muatan NilaiNilai Karakter Melalui Permainan Tradisional di PAUD Among Siwi, Panggungharjo, Sewon, Bantul. Jurnal JIPSINDO No. 1, Volume 2, Maret 2015.

Tadkiroatun Musfiroh. (2008). Cerdas melalui bermain. Cara mengasah multiple intelligence pada anak sejak usia dini. Jakarta: Grasindo.

Wina Sanjaya. (2008). Strategi Pembelajaran, Berorientasi Standar Proses Pendidikan. Jakarta: Kencana Prenada Media.

Vincentius Endy Santosa \& Iin Mendah Mulyani. (2008). 100 permainan kreatif untuk outbound dan training. Yogyakarta: Penerbit Andi 